Andriela Vitić-Ćetković, $\mathrm{PhD}^{1}$

University of Montenegro,

Faculty of Tourism and Hotel Management

Bojan Krstić, $\mathrm{PhD}^{2}$

University of Niš, Faculty of Economics

Ivona Jovanović, $\mathrm{PhD}^{3}$

University of Montenegro,

Faculty of Tourism and Hotel Management
SCIENTIFIC REVIEW ARTICLE doi:10.5937/ekonomika1502029V

Received: March 24, 2015

Accepted: April 24, 2015

\title{
IMPROVING THE TOURIST DESTINATION IMAGE WITH INTANGIBLE CULTURAL HERITAGE: MONTENEGRO AS A CASE STUDY
}

\begin{abstract}
As contemporary tourism moves increasingly towards adopting an experience economy, tourist experience based on intangible cultural heritage is becoming the important element of destination image, as a set of consumer perceptions about the destination. Sustainable tourist valorization of intangible cultural heritage may be particularly important for image of countries like Montenegro, with limited resources, including natural resources, capital and population of 620029 inhabitants (Monstat, 2011). Another reason is related to the country's tendency to diversify its tourism offer and attract new market segments who are motivated by cultural heritage, manifestations, ethnographic values, etc. In this paper, the authors evaluate current issues in Montenegrin tourism and the need for improving a tourist destination image based on safeguarding and promotion of intangible cultural heritage. Marketing respond on those issues may increase Montenegro's contribution to a common European identity and strengthen a sense of belonging the destination within a common European cultural space. The research in this paper is focused on desk research, induction, deduction, statistics, and analyzing the case studies.
\end{abstract}

Keywords: tourist destination, image, intangible cultural heritage

JEL classification: M31

\footnotetext{
1 andrielavitic@yahoo.com

2 bojan.krstic@eknfak.ni.ac.rs

3 ivonaj@t-com.me
} 


\title{
УНАПРЕЪЕЊЕ ИМИЏА ТУРИСТИЧКЕ ДЕСТИНАЦИЈЕ НЕМАТЕРИЈАЛНОМ КУЛТУРНОМ БАШТИНОМ: ПРИМЕР ЦРНЕ ГОРЕ
}

\begin{abstract}
Апстракт
С обзиром да савремени туризам у растућој ери усваја концепт економије искуства, туристичко искуство базирано на нематеријалној културној баштини постаје важан елемент имица туристичке дестинације, као скупа периепција потрошача - туриста о дестинащији. Туристичка валоризација нематеријалне културне баштине на одрживим основама може бити посебно важна за имиц земаља попут Црне Горе са ограниченим ресурсима, укључујући природне ресурсе, капитал и популачију од свега 620.029 становника (Monstat, 2011). Други разлог је повезан с тенденцијом земље да диверзификачије своју туристичку понуду и привуче нове тржишне сегменте који су мотивисани културном баштином, манифестацијама, етнографским вредностима, итд. У овом раду, аутори евалуирају текуће изазове у туризму Црне Горе и потребу за унапређењем имица туристичке дестинаиије који се темељи на очуваюу и промоцији нематеријалне културне баштине. Маркетинг одговор на дате изазове може дати допринос Црне Горе заједничком европском идентитету и јачати осећај припадности дестиначије заједничком европском културном простору. Истраживање у овом раду засновано је на анализи постојеће литературе, индукиији, дедукцији, статистичким методама и анализи студија случаја.
\end{abstract}

Кључне речи: туристичка дестинација, имии, нематеријална културна баштина

\section{Introduction}

The image is a kind of net result of the interaction of all the experiences, beliefs, feelings, and impressions which each stakeholder has in connection with an organization. The primary objective of image management is creating the intended or targeted image, as well as creating a favorable reputation in the minds of key stakeholders (Krstić, Krstić and Ivanović, 2013). A good image in public, over a longer period of time, creates a reputation which contribute to improving the financial performance and long-term competitive advantage (Krstić, 2014; Krstić, 2014a).

Destination image represents the sum of all beliefs, ideas and impressions that people associate with a destination (Crompton, 1979; Kotler, Haider and Rein, 1993). Nowadays, with its global presence, tourism has a vital role in safeguarding culture. On the other side, tourism is becoming an increasingly important factor in promoting national identity, especially in small countries in transition that are most often affected by the negative aspects of globalization. Almost everywhere, identity is partly created out of the images constructed or reproduced by tourists (Urry, 1994; according to Palmer, 1998). "Intangible cultural heritage is transmitted from generation to generation and is 
constantly recreated by groups in response to their environment, their interactions with nature and their history, providing them with a sense of identity and continuity." (http:// pub.unwto.org/). Intangible cultural heritage consists of specific knowledge, skills, traditional crafts, traditional instruments, folk art, customs etc. It represents a real and symbolic part of the national and destination's identity. Safeguarding the living heritage may also be a part of the tourism destination image as a sum of beliefs and impressions that people hold about a place.

The concept of intangible cultural heritage was recognized relatively late in terms of its protection: the UNESCO Convention for the Safeguarding of the Intangible Cultural Heritage recognized it in 2003 and it came into force in 2008. South Eastern European Countries (SEE) made the ratification of the Convention, but intangible heritage of Montenegro is neither sufficiently investigated nor protected.

The concept of economy of experience is recent, while experience is a phenomenon which is linked to culture, tourism, entertainment, marketing, etc. Proponents of economy of experience (Pine, Gilmore, 1999) viewed it as a key element of the value of a tourist destination, considering that modern tourists seek not only a product or service, but the experience that they will remember, in relation to a given product or service.

\section{Current facts about Montenegrin tourism development}

Tourism has played an important role in the Montenegrin economy since 1950s. However, up till 1990s Montenegrin tourism image was identified as an overall Yugoslav image of cheap and mass tourist destination. In spite of different tourist attractions that are scattered all over the country, tourism in Montenegro has always been mainly centered in the coastal region. After the 1990s crisis Montenegro is trying to create a new image based on the model of tourism development that is more sustainable and more diversified in terms of an offer, which includes sustainable cultural tourism. Currently, tourism represents the main industry in Montenegro.

World Travel \& Tourism Councils (WTTC) ranks Montenegro, among the 184 countries where tourism is one of the priorities in the development, at the following positions: 135th place of the absolute size in 2013, ranked 36th by the amount of contributions to GDP in 201, the first place according to the forecast growth rate in 2014 and the first place to the long-term growth forecast (period 2014-2024) (www.cdm.me/ turizam/).

According to the Report from 2014, Montenegrin total (direct and indirect) contribution to GDP from travel and tourism was 714.2 million (20 percent of GDP) in the 2013. It is expected to increase of 8.8 percent on average per year in the next ten years (1877.3 million, or 37.2 percent of GDP in 2024th) (www.cdm.me/turizam/). Furthermore, 1,492,006 tourist arrivals were recorded in Montenegro in 2013 which is $3.6 \%$ more than in 2012, while the number of overnight stays of $9,411,943$ is higher by $2.8 \%$. Of these, $89.4 \%$ were foreign tourists and $10.6 \%$ domestic tourists. Most overnight stays in 2013 were realized by tourists from Russia (28.1\%), Serbia (25.1\%), Bosnia and Herzegovina (7.5\%), Ukraine (5.6\%), Poland (2.7\%), Germany (2.3\%) and France $(2.2 \%)$. Tourists from other countries realized $23.2 \%$. As regards the density of overnight stays in tourist areas in 2013, the highest rates were recorded in coastal 
areas $(97.0 \%)$, capital (1.2\%), mountain areas (1.1\%) etc.(http://aktuelno.me/ekonomija/ monstat-crnu-goru-posjetilo-15-miliona-gostiju).

The primary document that was supposed to establish a new competitive position of Montenegro after the conflict in former Yugoslavia in 1990s was the Master Plan - Tourism Development Strategy of Montenegro by 2020, which was adopted in 2001. In this strategic document, Montenegro was described as a competitive tourist destination: in the first half of the year a high quality Mediterranean destination and in the second half of the year a destination for an active vacation. Meanwhile, Montenegro has made some improvements regarding infrastructure, promotion, structure and hotel accommodation, etc., but the basic problem was the lack of the Master plan's implementation. The revised version of the Master Plan was adopted in 2008 and its focus is on the diversification of tourism offer based on unique and highquality tourist experience. Accordingly, orientation towards new market segments, including more responsible tourists who do not prefer mass tourism experience, was emphasized.

The fact is that there are many challenges associated with new, sustainable tourism directions in Montenegro. Particular effort must be made in trying to attract new segments of tourists. The candidate status for the EU membership is one of the things that affect the need for creating further approaches for development of the tourist destination image, including strategies for valorisation of intangible culture through tourism.

\section{Intangible cultural heritage of Montenegro and in the context of tourist destination image}

"Cultural tourism-that is, tourism with the objective (among others) of experiencing cultural heritage, whether tangible or intangible - is an expanding segment, and it seems likely that growth will continue in the long term" (http://unesdoc.unesco. org/images/0017/001787/178732e.pdf.). Tourists are seeking more and more to fully interact with local cultures and experience the global variety of arts, handicrafts, rituals, cuisines etc. Accordingly, there are 6 typical areas that connect tourism and intangible cultural heritage: handicrafts and the visual arts; gastronomy; social practices, rituals and festive events; music and the performing arts; oral traditions and expressions and knowledge and practices concerning nature and the universe" (http://ethics.unwto.org/ en/content/tourism-and-intangible-cultural-heritage).

Intangible cultural heritage may be a powerful force in creation and maintenance of a tourist destination image because it relies upon specific historic symbols as a means of attracting tourists. In the Southeast Europe, in Turkey a joint declaration on the intangible cultural heritage and its safeguarding was adopted on December 17, 2009. The emphasis was also placed on multinational nominations for the UNESCO list. Actually, intangible goods which are located in several countries usually run for multinational nominations. Montenegro has recently created the conditions for protection of its living tradition, by enforcement of the Law on Ratification of the Convention on Intangible Heritage in 2009 and the Law on Protection of Cultural Property in 2010.

Intangible cultural heritage is a type of living heritage that is being constantly renewed and that evolves in accordance with the environment. It has to be traditional, but still alive, that unifies past, present and future. It constitutes an important part of the 
cultural heritage because it provides a sense of identity and belonging to a particular community (Jovanović, Vitić-Ćetković, 2013). Local communities are the main actors in the creation and transmission of intangible cultural heritage: they are its creators, guardians and transmitters (Harris, Griffin, Williams, 2002).

From the standpoint of a tourist destination image, local communities need to spread the "spirit of the place", where the "spirit" refers to the thoughts, the man and the immaterial, while "place" evokes the geographic location, the physical world, in short the material elements. Therefore, "spirit of the place" is one dynamic relationship between material (sites, landscapes, buildings) and spiritual elements (rituals, legends, customs, festivals, arts) that breeds a sense, meaning and emotion (Turgeon, 2010).

At the end of 2012, Montenegro drew up an initial list of 178 customs, skills, arts, crafts - living tradition that were proposed and some of them may be placed on the list of world intangible cultural heritage. In comparison with the region, Croatia has already placed 12 living traditions on the UNESCO list; Serbia sent 27 proposals, while Montenegro has just started the list (http://www.vijesti.me/kultura/crnogorskanematerijalna-kulturna-dobra-od-gusala-gadanja-kokota-clanak-107418).

The cult of St. Vladimir, religious ceremony dedicated to St. Tryphon, Dobrotska lace, Durmitor's legends, Boka Navy, Fašinada are some of the proposals listed by Montenegro for nomination to the UNESCO list of the Intangible Cultural Heritage. In this paper, 3 intangible cultural goods from coastal, mainly mass tourism region of Montenegro were selected for evaluation.

The cult of St. Vladimir and traditional procession of bringing the cross on the mountain Rumija, near the town Bar on St. Trinity day, represents a thousand year old tradition. It is a unique heritage of the people of all three religions (Orthodox, Catholics and Muslims) that live in this area. This cult is one of the oldest cults in southeastern Adriatic and one of the oldest Christian cults in Europe. The cross is connected to Doclean Prince Vladimir (980-1016) who was according to some historical data, the first ruler of the first nominally independent Montenegro - Doclea. Prince Vladimir was proclaimed a saint, while the cult of St. Vladimir is honored not only in Montenegro, but also in Macedonia, Bulgaria and northern Greece, and therefore belongs to living traditions of Montenegrin, Balkans' and European culture.

Figure 1: St. Tryphon's dance circle

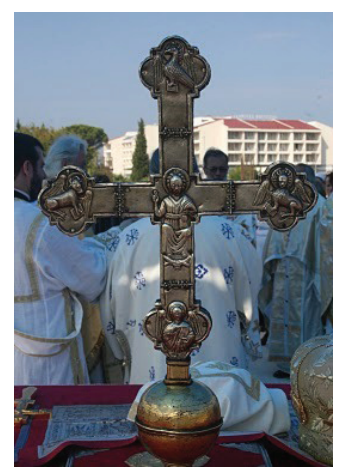

Source: https://www.google.me/search?q=izno\%C5\%Alenje+krsta+na+rumiju\&tbm=isch\&imgil 
The religious ceremony dedicated to St. Tryphon, the patron saint of the town of Kotor, whose relics are kept in Kotor's cathedral, represents a 12 century old tradition. According to the tradition, in 809, sailors from town of Kotor who were present at the arrival of the ship which brought the relics of St.Tryphon, performed the typical St. Tryphon's dance, which today characterizes the religious ceremonies of St. Tryphon. That year, the Fraternity of seafarers was formed, and nowadays it is one of the oldest in the world - Boka Navy. From 1979, the Natural and Culture - Historical Region of Kotor is a World Heritage Site.

Figure 2: St. Tryphon's dance circle

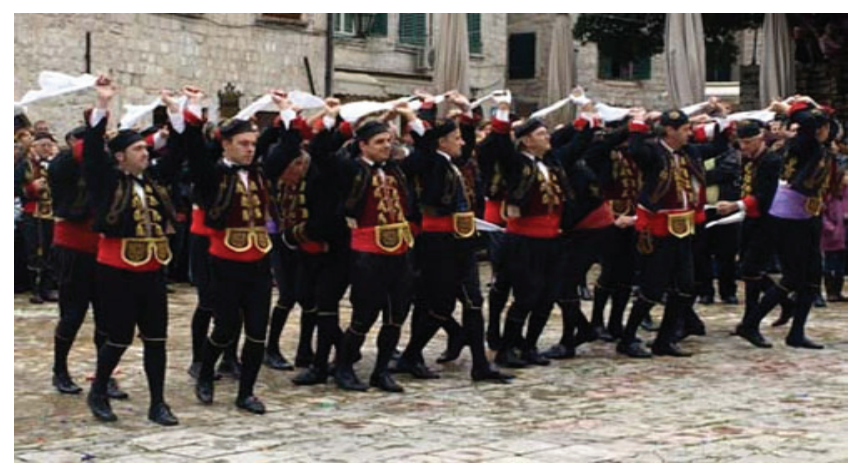

Source: https://www.google.me/search?q=kolo+boke $\% \mathrm{C} 5 \% \mathrm{~A} 1 \mathrm{ke}+$ mornarice\&tbm=isch\&tbo=u\&s ource $=$ univ\&sa $=$ X\&ei $=$ b0vKU4KACuHnywOv6YGAAw\&ved=0CDIQ7Ak\&biw=1024\&bih=610

Figure 3: St. Tryphon's dance circle

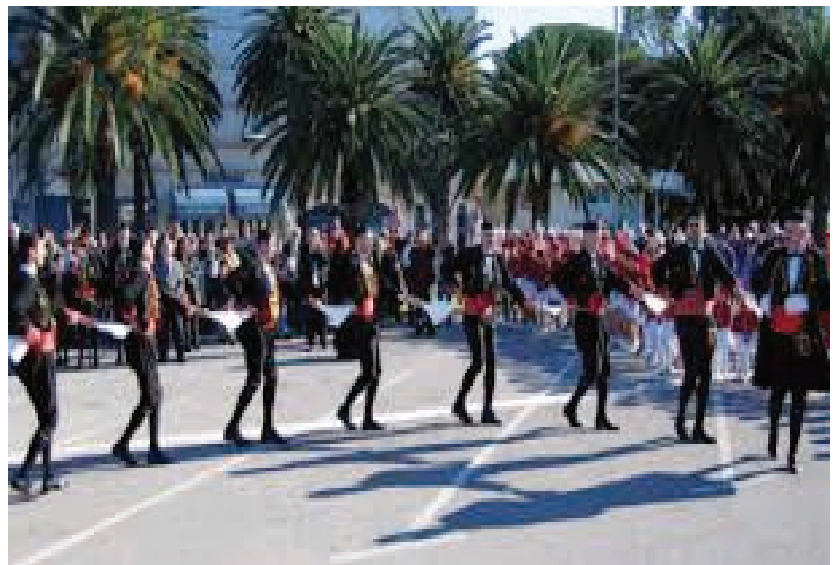

Source: https://www.google.me/search?q=kolo+boke\%C5\%A1ke+mornarice\&tbm=isch\&tbo=u\&sou rce=univ\&sa=X\&ei=b0vKU4KACuHnywOv6YGAAw\&ved=0CDIQ7Ak\&biw=1024\&bih=610

Making Dobrotska lace is a traditional craft which dates from the 12th century, whereas the first records originate from the 15th century. In the Middle Ages and later, 
on the east Adriatic coast there were manufactories for making Gothic and Renaissance handiwork of high artistic value. One of them was located in Dobrota, whose residents were engaged in shipping and trade, and were exposed to different cultural influences. Local sailors were bringing home the various items from their travels, including the lace. It had inspired the women from Dobrota to commit to specific skills of making lace, which they partly sold and partly gave away to churches. Nowadays, the local community organizes workshops for making Dobrotska lace, in order to preserve and promote this unique embroidery.

Figure 4: Dobrotska lace

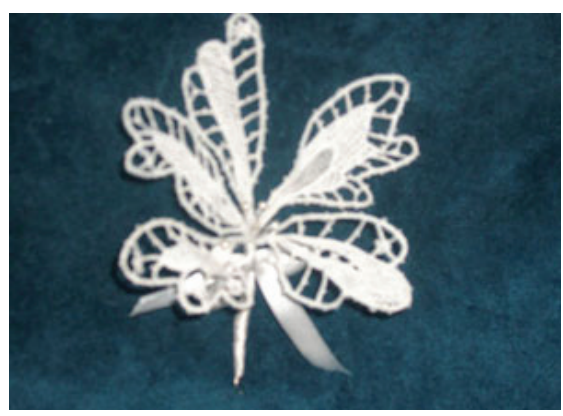

Source: http://nebeskiprsten9.blogspot.com/2013/02/od-legende-o-prutasu-do-svadbe-u-grblju.html

Figure 5: Dobrotska lace

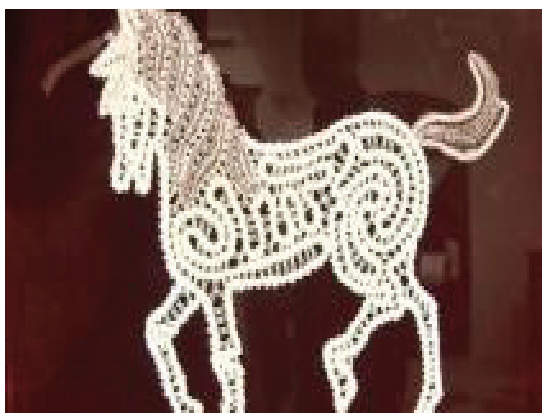

Source: http://www.vesti.rs/Vesti/Dusa-dobrotske-cipke-2.html

These examples show the need for Montenegro to be strategically placed as intangible cultural heritage.

An interesting approach for the valorization of intangible cultural heritage may be «Scheherazade strategy» (Salmon, 2011) which is based on the following activities:

1. Presentation of heritage through a story that represents the destination's identity - Storyline

2. Placement of stories in the desired time - Timing

3. Emphasis of messages or to highlight destination's attractions - Framing 
4. Networking via Internet, etc. in order to attract the appropriate tourist niches - Networking

Anyhow, orientation towards the safeguard and promotion of its intangible cultural heritage can be one of the approaches to raise the tourist destination image, extend the season, encourage extension of tourists staying at the destination, stimulate consumption during their stay, etc. Challenges to overcome in Montenegro include the need for redirect the tourist destination image to better reflect the region's history and better shift towards new and demanding market segments. Anyway, the local community has to be involved in promoting the "spirit of place", thus providing authentic visitors' experience and expanding the tourist destination image.

\section{Conclusion}

Competition in the global tourism market requires innovative approaches in tourism development. Montenegro, a country where tourism is the main developmental strategy tends to redirect its image and attract new market segments, including ones motivated by cultural heritage, events, education, ethnographic values, etc.

Montenegro's step towards the European Union imposes an obligation to safeguard the tangible and intangible culture with the aim of contributing to its diversity. That can also involve regional cooperation in the Southeastern Europe due to the common intangible cultural heritage that has to be properly protected and jointly promoted in terms of region's tourism positioning. On the other hand, responsible tourists may become our partners that support conservation of heritage, contribute to the spread of "spirit of place" as a unique destination experience in an increasingly globalized world. Anyhow, the intangible cultural heritage in Montenegro must be thoughtfully managed and used in a sustainable manner if it is to survive and contribute to recognizable tourist destination image.

\section{References}

Dickinson, J., Lumsdon, L. (2010): Slow Travel and Tourism, London-Washington, DC: Earthscan Publications Ltd.

Hall, D., Richards, G. (2002): Tourism and sustainable community development, Routledge, London

Harris, R., Griffin, T., Williams, P. (2002): Sustainable Tourism-A Global Perspective, Butterworth - Heinemann, Boston

http://aktuelno.me/ekonomija/monstat-crnu-goru-posjetilo-15-miliona-gostiju (15.3.2015.)

http://ethics.unwto.org/en/content/tourism-and-intangible-cultural-heritage (15.3.2015.)

http://nebeskiprsten9.blogspot.com/2013/02/od-legende-o-prutasu-do-svadbe-ugrblju.html (15.3.2015.)

http://pub.unwto.org/WebRoot/Store/Shops/Infoshop/50B8/AA74/FFA9/31D4/CE96/ C0A8/0164/14DB/121130_intangilbe_cultural_heritage_excerpt.pdf(15.3.2015.) 
http://unesdoc.unesco.org/images/0017/001787/178732e.pdf. (15.3.2015.)

http://www.cdm.me/turizam/crna-gora-na-prvom-mjestu-po-brzini-rasta (15.3.2015.)

http://www.vesti.rs/Vesti/Dusa-dobrotske-cipke-2.html (15.3.2015.)

http:/www.vijesti.me/kultura/crnogorska-nematerijalna-kulturna-dobra-od-gusalagadanja-kokota-clanak-107418 (15.3.2015.)

https://www.google.me/search?q=izno $\% \mathrm{C} 5 \% \mathrm{~A} 1$ enje+krsta + na + rumiju\&tbm=isch\&i mgil (15.3.2015.)

https://www.google.me/search?q=izno $\% \mathrm{C} 5 \% \mathrm{~A} 1$ enje+krsta + na + rumiju\&tbm $=\mathrm{isch} \& \mathrm{i}$ mgil (15.3.2015.)

https://www.google.me/search?q=kolo+boke $\%$ C5\%A1ke+mornarice \&tbm $=\mathrm{isch} \& \mathrm{tb}$ $\mathrm{o}=\mathrm{u} \&$ source $=$ univ\&sa $=\mathrm{X} \& \mathrm{ei}=\mathrm{b} 0 \mathrm{vKU} 4 \mathrm{KACuHnywOv6YGAAw \& ved=0CDIQ}$ 7Ak\&biw $=1024 \&$ bih $=610(15.3 .2015$. $)$

https://www.google.me/search?q=kolo+boke $\% \mathrm{C} 5 \% \mathrm{~A} 1 \mathrm{ke}+$ mornarice $\&$ tbm $=\mathrm{isch} \& \mathrm{tb}$ $\mathrm{o}=\mathrm{u} \&$ source $=$ univ\&sa $=\mathrm{X} \& \mathrm{ei}=\mathrm{b} 0 \mathrm{vKU} 4 \mathrm{KACuHnywOv6YGAAw \& ved=0CDIQ}$ 7Ak\&biw $=1024 \&$ bih $=610$ (15.3.2015.)

Jovanović, I., Vitić, A. (2009): Marks of French culture and cultural tourism development in Cetinje, historical capital of Montenegro, El turismo en el Mediterráneo: posibilidades de desarrollo y cohesión, Margarita Latiesa Rodríguez, Inmaculada Puertas Cañaveral, José Luis Paniza Prados (editors), Editorial Universitaria Ramón Areces, Madrid, Spain

Jovanović, I., Vitić-Ćetković, A. (2013): La promotion de l'héritage culturel immatériel au Monténégro en vue du développement touristique durable, Contesti mediterranei in transizione: La mobilità turistica tra crisi e mutamento, Edited by Romina Deriu, Franco Angeli, Italia

Krstić, B., Krstić, S., \& Ivanović, V. (2013). Identitet, imidž i reputacija - determinante konkurentnosti preduzeća. Ekonomika, 59(1), 26-35.

Krstić, B., (2014): Upravljanje intelektualnim kapitalom preduzeća, Ekonomski fakultet, Niš

Krstić, B., (2014a): Reputation and Financial Performances of a Company, Facta Universitaties - series Economics and Organization, 11 (1), 2014, 37-46.

Monstat (2013): Montenegro in Figures, Podgorica

Pine, B.J., Gilmore, J., H. (1999): The Experience Economy: Work is Theatre \& Every Business a Stage, Harvard Business Press

Richards, G. (1999): European Cultural Tourism: Patterns and Prospects. in: D. Dodd \& A. Van Hemel (editors) Planning Cultural Tourism in Europe: A Presentation of Theories and Cases. Amsterdam, Boekman Foundation/Ministry of Education, Culture and Science

Rovinski, P.A. (2004): Crna Gora u prošlosti i sadašnjosti, Etnografija Tom II, Obod, Cetinje

Salmon, Ch., (2011): Strategija Šeherezade, Clio, Beograd

Turgeon, L. (2010): L'esprit du lieu:entre le patrimoine matériel et immatériel, Collection Patrimoine en mouvement, Presse de l'Université Laval, Paris 